\title{
O. KHALABUDENKO
}

Oleg Khalabudenko, Ph.D. in Law, Associate Professor, Associate Professor of Kyiv National University of Construction and Architecture*

ORCID: 0000-0001-9478-0164

\section{A CRITICAL LOOK AT THE POLICY OF LAW IN THE CONTEXT OF THE REFORM OF THE CIVIL CODE OF UKRAINE (SOME METHODOLOGICAL REMARKS)}

\section{Introduction or what modern civil law owes to the past}

Civil law, in terms of its content and form established in the 19th-21st centuries, is a phenomenon of Continental law. Herewith, the content of law for Continental law is thought of as a set of permissions, prohibitions, obligations, rewards and recommendations that legal order recognizes as necessary to approve, put into effect and protect in a society existing in a specific historical dimension.

The law of states that experienced in the 20th century the powerful influence of the totalitarian socialism practices and legal doctrines justifying such practices has adjoined to Continental law. These were, certainly, post-Soviet countries including Ukraine, which are currently in the process of seeking a legal self-identification.

The difficulty of legal reforms are predetermined in these jurisdictions, on the one hand, by the intention to find civilizational grounds in the bowels of Continental law for building national legal systems, and on the other hand, by the obvious need to take into account the current experience of convergence as being established in the nuclei of legal orders united by the Western legal tradition common for Continental and Anglo-American law. At the same time, even a cursory glance at the law of these states suggests a growing trend towards the formation of more "technocratic law": legal acts here are increasingly being developed in the technical documentation style, rather than as the legislation designed for implementation in the context of the legal equality for the legal communication participants.

This trend, according to William Elliott Butler, is largely motivated by the "lack of a clear doctrine and principle on the inadmissibility of state intervention in the sphere of social life ${ }^{1}$. The mentioned tendency is taking place against the backdrop of technological changes which in turn lead to a weakening role and importance of a free scientific discussion and an increase of normative texts. It should be noted that these trends are particular for Ukraine, and this requires special research. It seems the fair point that "Ukraine is one of the technocratic legal systems"2.

Western legal tradition arose as a result of autonomous socio-cultural processes that had had a revolutionary character characteristic only of European culture. Initially, the Western legal tradition was based on a synthesis of reformed Roman law (Ius commune), ancient philosophy and Christian theology ${ }^{3}$.

Assessing critically the components of the Western legal tradition "matrix" (in the version of Usus Modernus Pandectarum), we note first of all that the content, being considered close to reality, and the spirit of Roman law are not really revealed "at the stage of the pandectists". And it is by no means in the jurisprudence of concepts that one should see "the reproduction of the positive content of Roman law" and, even more, "the way of thinking of Roman lawyers"4. On the contrary, the evolution of Roman law, its ideas became understandable only after the practical implementation of working-out of pandectists who had rejected the glossators and commentators' ideas in Civil codes of the New Age (first of all, on the permissibility of sharing legal dominance between personally dependent individuals). In other words, only the termination of Roman law (before this it had undergone three stages of revival) in almost all jurisdictions relating to the Western legal tradition, its ideas could be understood and used, but, as a rule, only as an introduction to modern private law. This is in the best case: there were extremely few knowledge holders of Roman law tradition on the continent. Thus, we should agree with the Reinhardt Zimmermann's view that "... the high hopes and expectation entertained at the time of the Enlightenment have not been fulfilled: neither have the codifications made the learned lawyer redundant, nor have they led to a lasting consolidation (ossification) of private law"5.

II. Is the codification of civil law the only true way of the law genesis and law-making?

In this regard, the codifications of the 19th-20th centuries being guidance for the Eastern European states should be characterized as anti-feudal law rather than promising "bourgeois law". Especially since modern law must comply with the basic parameters of a post-industrial society.

Moreover, historical Roman law with its "casuistic nature of court decisions, the origin of principles and rules of law from cases, the use of the technique of analogies" 6 was much closer to modern case law than to Continental law. The strong idea by Oliver Wendell Holmes that "the life of the law has not been logic: it has been an experience"7, turns out that Roman law to be much closer to modern case law than to Continental law.

There is also no trace of the Stoics in the modern civil law doctrines: the current worldview and the prevailing private-law political and legal approach are based on utilitarianism and, accordingly, sees in the law by no means a

(C) O. Khalabudenko, 2020

* Олег Анатолійович Халабуденко, кандидат юридичних наук, дочент, дочент Київського національного університету будівництва і архітектури 
metaphysical idea, but only "its instrumental essence" regulator" alienated from the right holder.

There was also not much left from Christian theology in modern civil law. This is observed in a slight residual sacralization of the civil code text itself (similar to Scriptura Sacra), whose authority has long been "adjusted" by the constitutionalism doctrine, as well as in the doctrine of the sanctity of the contract (pacta sun servanda) in the form when it is not limited by the principle of effective violation of the contract borrowed from American law.

It should be noted that, in contrast to Continental law, Anglo-American law (often referred to as Common Law) is characterized by a strong judiciary, and as a consequence, by the precedent nature of law. It is also distinguished by indirect borrowing of the Roman law material (through the doctrine, first thanks to the activities of the Oxford and Cambridge universities, where Roman law was stated as a written reason, while common law was mastered in bar associations replenishing ranks of magistrates), as well as by the focus on the practical implementation of law with a characteristic priority of procedural law over the substantive one.

The Common law method is close to Roman law in which intuition based on the principle of justice, despite logical and systematic criteria, is still of great importance in judges' decisions ${ }^{9}$. In turn, Continental law, due to welldefined historical conditions of its formation, has learned the experience that the ratio decidenti of magistrates is determined by a normative statement enshrined in a codified act. The methodological approach formed in Continental law at some historical period seemed to be so attractive and natural that the founders of the historical school of law (XIX century) considered it as a "universal regularity of genesis of law".

So, in the second half of the 19th century, J. Phillimore argued that "the natural progress of law goes through three periods: the "infant period" (the rule of custom), the period of the complication of law (the rule of case law) and the period of the pinnacle of evolution (codification of law)"10. The fact that "Continental law, in the presence of legal norms in the form of codes accessible to all, is characterized by predictability and stability of legal consequences which are not dependent on judicial discretion"11 is also a positive feature.

Thus, researchers of legal phenomena recognize that the meaning of a norm on the continent, by virtue of its clear verbal wording, is considered constant, independent of the subject of interpretation, and this allows to "apply" uniformly the norm in resolving many "single-row" legal cases; however, in case law, there seems to be no such degree of formal certainty and constancy of the meaning of the legal "norm"12.

In any case, the "popularity" of Continental law (according to some statistics, 2/3 of the world's population applies Continental European law ${ }^{13}$ ) can hardly be explained solely by the factors mentioned above. Most likely, once prevailing military, technological, and cultural-legal Eurocentrism had a significant influence on the spread of this model of legal life organization.

\section{The origins of civil law policy}

The methodological error in understanding the peculiarities of Continental law, in our opinion, is a misconception about the main component of law - its norm. Obviously, there is a need for a consequent deconstruction of the "norm of law" concept. In other words, we are talking about emphasizing of certain aspects in the general legal category "norm of law", namely: "normative statement" considered as the central element of the legal system, "normative rules" serving as a leading model for assessing the behaviour of a participant in legal communication in law activities, "rule of conduct" as the basis for the obligation of legal communication subjects.

The necessity of the proposed differentiation of the concepts is predetermined by the specificity of the reference to the acting subject of legal reality, and, accordingly, the function that these terms (normative statement, normative rules and rule of conduct) perform in the process of legal communication. The gap between the normative rule as an abstract directive prescription and the particular rule of behavior that guides the subject is filled in case of a dispute with the value obtained in the practice of the normative rule applying ${ }^{14}$.

The notion that the normative statement is a norm of law is specific for Continental law jurisprudence due to certain legal grounds: legal dogma in Europe was formed in isolation from practice, within universities. There, by virtue of giving the civil law text sacred power, an initial point of view is formed that the rule, generalized and enshrined in the text, serves as a regulating principle for practice. However, this point of view is unfounded. Normative statements, fixed most often in the normative legal act, including the civil code, are adopted in accordance with certain procedural rules applicable in the law-making process. In this sense, the development and adoption of normative statements relate to the field of public (state) law. The subjects of can only believe in the good faith, honesty, and reasonableness of the legislator, who oversees the development and adoption of the respective normative act.

We recall that until the triumph of the constitutionalism doctrine, in order to avoid government interference in the affairs and interests of private individuals, the Civil code in the countries of Continental law had the status of an economic constitution, acting in the individuals' property sphere, while the political constitution covered exclusively public law aspects of the life of society as a whole. However, current Civil codes are based on the constitution and must comply with it. So, the 1 st paragraph of article 4 of the Civil Code of Ukraine expressly provides: "The Constitution of Ukraine shall constitute the framework of the civil legislation of Ukraine"15.

The doctrine of the "horizontal effect" of constitutional norms, assuming that constitutional principles (derived from the normative material of the constitution itself) serve as a "normative umbrella disclosed above all legislation," suggests that each civil law norm must be compatible with the system of constitutional values and must be interpreted in keeping with the spirit of this system ${ }^{16}$. Thus, the stability of the legal regime, prevailing in the sphere of private law, depends on the stability of the sphere of public law that is very mobile in modern conditions.

Nonetheless, it seems near-sighted not to take into account the trend that arises in this regard, especially when it comes to the modernization of the civil legislation of Ukraine which proclaimed "the irreversibility of the European and Euro-Atlantic course of Ukraine"17 in the preamble of the Constitution. In any case, no matter how strong is the desire to endow the normative statement of the civil law codifications with sacred meaning, one should not 
expect a miracle since the normative statement enshrined in the text does not coincide with the normative rule and rule of conduct. Indeed, the value of law in its only true meaning of constant and unchanging will (perpetuum voluntas) is determined not by beautiful phrases often resembling slogans on banners of the past, but by the authority of the judiciary based on reason and power of legal order. The above factors that do make some of the jurisdiction attractive in terms of protection of the rights to legitimately appropriated resource, as well as assets invested in the future. In this sense, the definition that "law is a general command, a decision of persons secured by the judiciary $<\ldots>$, reflecting the general consent of res publica"18, is still true.

Is not worth, in our opinion, to overestimate the effectiveness of the indirect influence on national Civil law of the unified acts of Soft Law, in particular, the Principles of European Treaty Law (PECL), the Principles of International Commercial Contracts (UNIDROIT), as well as the UN Convention on Contracts for the International Sale of Goods, certain provisions of which were borrowed by national codifications. Aimed to actions in international commercial circulation, the provisions of these and other "international acts" create additional unnecessary difficulties for participants in legal communication at the national level. Moreover, these acts were intended to harmonize the sphere of contractual obligation relations, while the harmonization of provisions on property and inheritance law remained outside the idea of establishing a homogeneous legal regime on the European continent.

We will be able to evaluate the effectiveness of the Model Rules of Private European Law (DCFR) "encroaching" on the systematization and unification of a significant part of the legal material traditionally related to civil law on the continent (general provisions, legal acts, law of obligations, as well as trusts, the legal idea of which was successfully borrowed from Common Law jurisdiction), only if they are actually translated into legal life. In our opinion, judging the effectiveness of the borrowed legal structure at the level of the legal act text is no more effective than the intention of the observer in the Plato's cave deprived of a full look to judge the reality by the shadows appearing on the walls of the cave.

\section{Some rhetorical questions instead of a conclusion}

Thus, the assertion that the codification of civil law in Ukraine is a "multi-level system, the macro components of which are at the top level (the idea of natural private law, the ratio of natural law to the law, the rule of law in private law, the system and principles of private law, the structure of positive (written) private law and the Civil Code of Ukraine, the universalism of natural and written private law, in particular, the adaptation of private law of Ukraine to the corresponding European Union law, etc.), and the theories of individual institutions, their parts and provisions are at the lower levels " 19 is true, but only at the level of the fixation the elements of this system in the corresponding normative statements (normative sentences). They are expressing a judgment about whether a situation is desirable or undesirable.

Whether the ideas embodied in the Civil code is implementing in practice, when assessing the individuals' behavior from the position of regulatory rules and, especially, from the position of rules of conduct that guide specific participants in legal communication, still remains a question. The definition of the vector of civil law development depends on the answer to the above question. Whether private Continental law will remain the "ideal concept" 20 that legal life aspires to, or, on the contrary, legal reality following centrifugal tendencies caused by the "magical attractiveness" of other reference jurisdictions, will increasingly move away from the once perceived rational ideal of Civil law?

1 William Elliott Butler. The Place of Ukraine on the Legal Map of the World//Journal of the Comparative Law. 2010. Vol. V. No 1. P. 3.

2 Idem. P. 4.

${ }^{3}$ See: Harold J. Berman. Law and Revolution: the Formation of the Western Legal Tradition. Cambridge, Massachusetts: Harvard University Press, 1983.

4 Tarasov N.N. Yuridicheskoe issledovanie i yuridicheskoe myshlenie: protivorechiya professional'nogo soznaniya //Byulleten' kluba konfliktologov. Krasnoyarsk, 1999. Vyp. 7. P. 3.

5 Zimmermann Reinhard. Roman Law, Contemporary Law, European Law: The Cibilian Tradition Today. Oxford University Press, 2004. P. 1.

6 Jalowicz, Herbert Felix. Roman Regulae and English Maxims/ Europa e il diritto romano: studi in memoria di Paolo Koschaker. Bd. 1. P. 215.

7 Oliver Wendell Holmes, Jr. The Common Law. University of Toronto Law School Typographical Society September, 2011. P. 5.

8 Karapetov. A.G. Ekonomicheskij analiz prava. - Moskva: Statut, 2016. P. 24.

${ }_{9}$ Garsia Garrido M.H. Rimskoe chastnoe pravo: Kazusy, iski, instituty. Moskva: Statut, 2005. P. 138.

10 Phillimore J.G. Private Law among the Romans from the Pandects. London, 1863. P. 16-17.

11 Lado Chanturiya. Kontinental'noe pravo i kodifikaciya grazhdanskogo prava/Grazhdanskoe pravo: sovremennye problemy nauki, zakonodatel'stva, praktiki. Moskva: Statut, 2018. P. 526

12 See: Les Droits de tradition civiliste en question / À propos des Rapports Doing Business de la Banque Mondiale URL: www.henricapitant.org/storage/app/media/pdfs/rapports_doing_business/Les_droits_de_tradition_civiliste_en_question.pdf

13 See: Global Competitiveness Report, 2009, World Economic Forum. URL: www3.weforum.org/docs/WEF_GlobalCompetitivenessReport_2009-10.pdf

${ }^{14}$ See: Halabudenko O.A. O normah prava voobsche i normah grazhdanskogo prava v chastnosti: nekotoryie metodologicheskie zamechaniya // Derzhava i pravo: Zbyrnik naukovyh prats. Serlya Yuridichni nauki. Vypusk 74 / In-t derzhavy i prava im. V.M. Koretskogo NAN Ukrayini. - K.: Vid-vo «Yuridichna dumka», 2016. P. 227-246.

15 The Civil Code of Ukraine. URL: http://teplydim.com.ua/static/storage/filesfiles/Civil\%20Code_Eng.pdf

16 Savchy`n M.V. Porivnyal`ne konsty`tucijne pravo: navchal’ny`j posibny`k. Ky`yiv: Yurinkom Inter, 2019. P. 17-18.

17 Constitution of Ukraine. URL: https://rm.coe.int/constitution-of-ukraine/168071f58b

18 Bracton on the Laws and Customs of England. Volume I, Introduction; Volume II. Translated, with revisions and notes, by Samuel E. Thorne. [Published in association with the Seiden Society]. Cambridge, Massachusetts: Belknap Press of Harvard University Press, 1968. P. 22. 
${ }^{19}$ Lucz` V. Do istoriyi rozrobky` ta pry`jnyattya cy`vil`nogo kodeksu Ukrayiny` (2003 r.) // Pravo Ukrayiny`, \#1, 2019. P. 16.

20 See: Khary'tonov Ye.O. Pry`vatne pravo yak koncept: poshuk parady'gmy”: monografiya/Ye.O. Khary`tonov, O.I. Khary`tonova. - Odesa, 2014. $804 \mathrm{p}$.

\section{Резюме}

Халабуденко О.А. Критичний погляд на правову політику в контексті реформи цивільного кодексу України (деякі методологічні зауваження).

Питання, пов'язані з актуальним станом цивільного права і перспективами його розвитку, визначаються процесами конвергенції правових систем. У цих умовах особливу увагу, на думку автора, слід приділити питанням зближення методологічних підходів, прийнятих серед відповідних юридичних спільнот. Автор критикує уявлення, що склалося в науці права про основні характеристики сучасного цивільного права як сфери правової дійсності в межах континентального права. Автор звертає увагу на необхідність прийняти до уваги життєвий досвід конвергенції, що відбувається в ядрах правопорядков, об'єднаних спільною для континентального і англо-американського права Західної традицію права.

У статті висловлені критичні зауваження про роль римського права для сучасного континентального права, піддана критиці ідея «універсального правогенеза», відзначені недоліки надмірного перебільшення ролі нормативного тексту для вирішення завдань, що виникають у сфері приватного права. Автор зазначає, що сучасне цивільне право втратило історичні підстави, які служили основою для європейського континентального права, внаслідок чого акцент зміщується виключно на фактор правової політики розвитку цивільного права. У той же час автор зазначає, що нинішній досвід конвергенції, що розвивається в ядрах правових порядків, об'єднаних західною традицією права, загальної для континентального і англо-американського права, повинен враховуватися при реформуванні цивільного права в Україні. Свої висновки автор підкріплює методологічним підходом про трирівневу організацію норм права, який демонструє недостатність і нестійкість нормативних висловлювань, закріплених в тексті цивільного законодавства. На думку автора, труднощі правових реформ зумовлені прагненням знайти в надрах континентального права цивілізаційні основи для побудови національної правової системи, актуальність яких оскаржується в контексті системної кризи цивільного права в Свропі. Автор також зазначає, що українська юридична спільнота не має чіткого бачення політики приватного права.

Ключові слова: Західна традиція права, континентальне право, цивільне право, римське право, конвергенція в праві, методологічні підходи в цивільному праві, Цивільний кодекс України, цивільно-правова політика.

\section{Резюме}

Халабуденко О.А. Критический взгляд на правовую политику в контексте реформы гражданского кодекса Украины (некоторые методологические замечания).

Вопросы, касающиеся современного состояния гражданского права и перспектив его развития, определяются процессами сближения правовых систем. В этих условиях особое внимание, по мнению автора, следует уделить вопросам сближения методологических подходов, принятых среди соответствующих юридических сообществ.

Автор отмечает, что современное гражданское право утратило исторические основания, послужившие основой становления европейского континентального права, в результате чего акцент сместился преимущественно на фактор правовой политики его развития. Отмечается, что нынешний опыт конвергенции, наблюдаемой в ядрах правовых порядков, объединенных Западной традицией права, должен быть принят во внимание при реформировании гражданского права в Украине. По мнению автора, трудности правовых реформ в Украине предопределены стремлением найти в недрах континентального права цивилизационные основания для построения национального права, тогда как актуальная значимость таких оснований в контексте системного кризиса гражданского права в Европе представляется неубедительной. Автор также отмечает, что украинское юридическое сообщество не имеет четкого видения частноправовой политики.

Ключевые слова: Западная правовая традиция, континентальное право, гражданское право, римское право, конвергенция в праве, методологические подходы в гражданском праве, Гражданский кодекс Украины, Гражданско-правовая политика.

\section{Summary}

Oleg Khalabudenko. A critical look at the policy of law in the context of the reform of the civil code of Ukraine (some methodological remarks).

The questions regarding the current status of Civil Law and its development prospects are being determined by the legal systems convergence processes. Under these conditions, the convergence of the legal methodological approaches accepted among the relevant legal communities is an essential issue.

The author notes the modern civil law lost the historical grounds that had been a base for European Continental law, as a consequence, the focus is shifting exclusively to the legal policy factor of civil law development. At the same time, the author remarks that the current experience of a convergence being developed in the nuclei of legal orders united by the Western law tradition common for the Continental and Anglo-American law should be taken into account for the civil law reformation in Ukraine. According to the author, the difficulties of legal reforms in Ukraine are predetermined by the commitment to find in the bowels of Continental law the civilizational grounds for building national legal systems, whose relevance is being disputed in the context of the civil law systemic crisis in Europe. The author also remarks that the Ukrainian legal community does not have a clear vision of private law policy.

Key words: Western legal tradition, Continental law, Civil law, Roman law, Convergence in the Law, Methodological approaches in civil law, Civil Code of Ukraine, Civil law policy. 